Gut, 1962, 3, 232

\title{
Intestinal reticulosis as a complication of idiopathic steatorrhoea
}

\author{
K. R. GOUGH, A. E. READ, AND J. M. NAISH \\ From the Department of Medicine, University of Bristol, and Frenchay Hospital, Bristol
}

EDITORIAL SYNOPSIS Three patients who had idiopathic steatorrhoea associated with reticulosarcoma of either the jejunum or the ileum are described. Previously reported cases with these features are reviewed and the suggestion is made that the reticulosis may arise as a complication of idiopathic steatorrhoea.

In 1937 Fairley and Mackie drew attention to a sprue-like syndrome occurring in patients with intestinal reticuloses. They stressed the clinical and biochemical similarities between their cases and those of idiopathic steatorrhoea. Since that time reference has been made to at least 29 patients with steatorrhoea who had been found at necropsy to have some form of reticulosis involving the small bowel. In every case the authors have assumed that the steatorrhoea was secondary to the reticulosis.

This paper describes three patients with steatorrhoea who developed a localized reticulosarcoma of the small bowel. In each case it seems probable that idiopathic steatorrhoea was the primary process and the neoplastic change a complication. Furthermore, of the 29 patients previously reported in the literature, 20 are reviewed (Table I) because of the possibility that they, unlike the remainder, were cases of idiopathic steatorrhoea who developed a reticulosis as a late complication.

The clinical features which may herald the presence of a reticulosis in patients with idiopathic steatorrhoea are discussed, and in such cases early laparotomy is recommended.

\section{CASE REPORTS}

CASE 1 A 59-year-old housewife was in good health until February 1955 when she developed abdominal distension, excessive flatulence, and diarrhoea. She began to lose weight but did not seek medical advice until July 1955, when she was admitted to hospital. On examination she looked ill, wasted, and anaemic. The tongue was smooth, red, and sore; angular stomatitis was present. The fingers were clubbed.

Investigations at this time showed haemoglobin $=85 \%$, M.C.H.C. $31 \%$, and W.B.C. $8,000 / \mathrm{c} . \mathrm{mm}$. Radiographs of the abdomen demonstrated multiple fluid levels in the small bowel with distension of some loops. These appearances were considered consistent with subacute small bowel obstruction and laparotomy was performed on 18 July 1955. At operation a markedly distended sigmoid was found; one loop was excised and end-to-end anastomosis performed. Post-operatively she developed vomiting and diarrhoea with increasing abdominal distension and a second operation was performed on $25 \mathrm{July}$, at which a grossly distended small bowel was found with one loop adherent to the previous anastomosis. This was freed and the bowel decompressed by a flatus tube.

Following the second operation her blood pressure remained consistently low, and, for the first time, idiopathic steatorrhoea was considered as the probable diagnosis. A five-day fat balance, with a daily intake of $50 \mathrm{~g}$. of fat, showed the average daily fat excretion to be $10 \cdot 2 \mathrm{~g}$.

Treatment was then started with a low-fat diet and vitamin supplements, and on this régime she improved and remained well until in 1958 diarrhoea recurred, with five or six motions per 24 hours. The stools were loose and watery, but contained no blood or pus. A new symptom also appeared-epigastric pain, colicky in character, and radiating through to the back. Each episode lasted about 30 minutes. She also began to lose weight again.

She was re-admitted to hospital on 26 December 1958 when she was noted to be pigmented and cachectic. The tongue was smooth. There was some ankle oedema. The abdomen was distended and there was audible and visible peristalsis.

Haemoglobin was $77 \%$. The red cells showed mild iron deficiency changes. A fat balance on a $50 \mathrm{~g}$. fat diet showed an average daily excretion of $8 \mathrm{~g}$. $X$-ray studies of the small bowel showed coarsening of the mucosal fold of the jejunum and ileum, with some dilatation of jejunal loops.

Because her condition had deteriorated a gluten-free diet was begun. Response to this, however, was disappointing and from 19 January 1959 Prednisolone was given. She then developed a high fever, suffered episodes 
of colicky abdominal pain, and continued to lose weight. On 24 February she developed severe lower abdominal pain, and laparotomy revealed a perforation of the ileum at the site of a lesion which biopsy proved to be an ulcerating reticulosarcoma. The perforation was closed and attached to the abdominal wall and a defunctioning entero-anastomosis performed. After this she developed a small bowel fistula, and finally died on 23 March 1959.

Necropsy The significant findings were enlargement of mesenteric lymph nodes which were infiltrated with tumour. In the lower ileum there was a tumour $5 \mathrm{~cm}$. in diameter, involving the whole circumference of the bowel. There was a large perforation $3 \mathrm{~cm}$. in diameter in the centre, where it was adherent to the abdominal wall anteriorly. The remainder of the small intestine was dilated, but showed no other naked-eye changes. Postmortem autolysis prevented an adequate microscopical examination of the mucosa. Histology showed a reticulosarcoma.

CASE 2 A 54-year-old man was admitted to hospital in January 1954 for investigation of glossitis, anaemia, and diarrhoea. He gave a history of passing pale, loose motions for about 20 years and stated that while in another hospital in 1936 he had been told that tests showed that his stools contained an excess of fat. Since that time he had avoided fat in his diet as much as possible, and apart from occasional episodes of diarrhoea, had remained well. On examination he was a thin, wasted man with angular stomatitis and a smooth red tongue.

Haemoglobin was $68 \%$ M.C.H.C. $27 \%$, W.B.C. $8,000 /$ c.mm., E.S.R. $7 \mathrm{~mm}$. in one hour. Faecal fat analysis showed an average excretion of $14 \mathrm{~g}$. per day on a 50 g. fat diet.

A diagnosis of idiopathic steatorrhoea was made.

He rapidly improved on a gluten-free diet, together with folic acid and ferrous sulphate by mouth. He adhered to the diet for about 12 months, during which time his general health was better than it had been for many years. However, his wife died in 1957 and he was then unable to keep to the diet. During 1959 the diarrhoea again became troublesome, so that he was passing 10 to 20 pale, loose, and offensive motions per day, but he refused to consider the gluten-free diet again because of domestic difficulties. He continued to lose weight and eventually was re-admitted in June 1960 . A new physical finding during this admission was an erythematous rash on the trunk and arms, associated with generalized pruritus (Fig. 1).

Haemoglobin was $110 \%$, M.C.H.C. $33 \%$, W.B.C. 11,800 per c.mm., with normal white cell distribution.

After $50 \mathrm{~g}$. glucose was given by mouth, the maximum rise in blood sugar was $21 \mathrm{mg} . / 100 \mathrm{ml}$. at half an hour.

A faecal fat analysis showed an average of $58 \mathrm{~g}$. of fat excreted per day on a $50-\mathrm{g}$. fat diet.

Small bowel studies showed flocculation of barium beginning in the upper jejunum, with multiple fluid levels. The small bowel appeared abnormally wide throughout with coarse mucosal folds.

A peroral jejunal biopsy (Fig. 2) showed that the histology of the mucosa was typical of idiopathic steatorrhoea.



FIG. 1. Case 2. Erythematous rash on forearm. The lesions also involved the trunk, and were associated with marked pruritus.

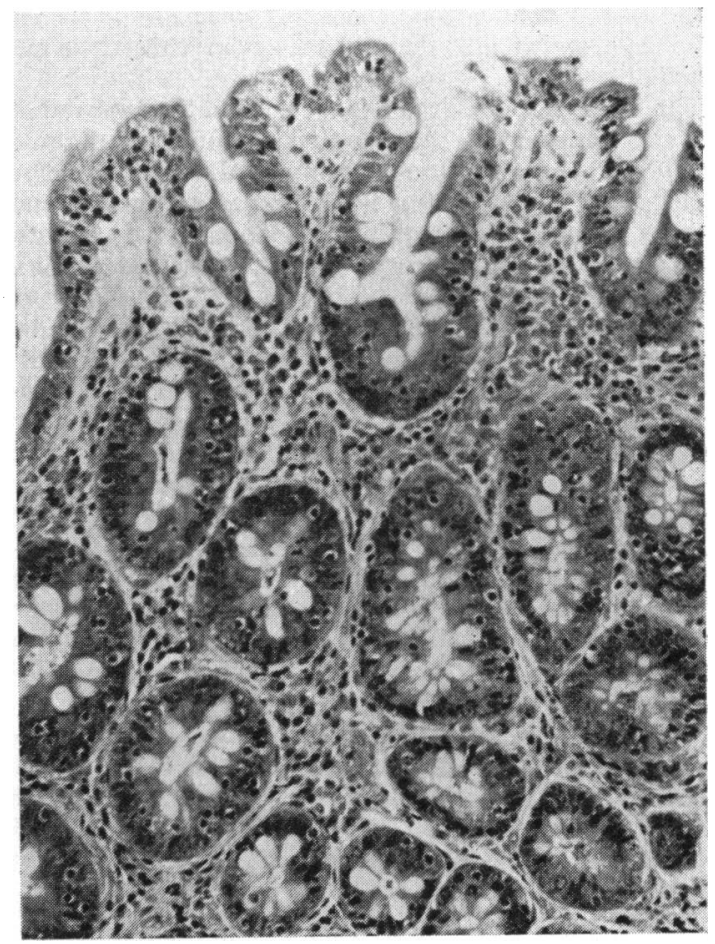

FIG. 2. Case 2. Peroral jejunal biopsy $(\times 175)$ showing subtotal villous atrophy compatible with idiopathic steatorrhoea. 


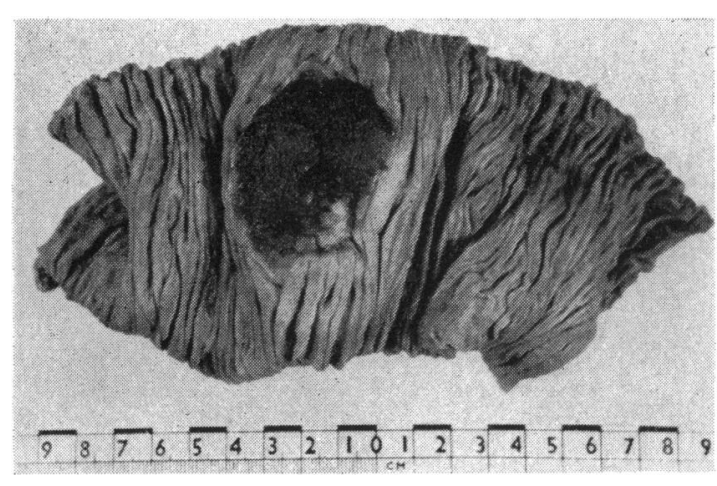

FIG. 3. Tumour in ileum (Case 2).

A gluten-free diet was started again, together with vitamin B supplements, calcium, and folic acid by mouth. There was some initial improvement with this régime, the stools being reduced to four per day, and he was discharged home on 10 July 1960 . However, when seen as an out-patient six weeks later he had lost a further $10 \mathrm{lb}$. in weight and so treatment with prednisone, $10 \mathrm{mg}$. b.d., was begun. There was some gain in weight, and by October 1960 the pruritus and erythematous rash had disappeared.

In December 1960 the patient noticed the appearances of two lumps on his scalp and his doctor referred him to a surgical clinic for biopsy and removal. However, before this could be arranged he was admitted as an emergency on 23 January 1961, with acute abdominal pain situated in the left hypochondrium. He felt nauseated and had vomited several times.

On admission he looked ill and two smooth, soft, but well-defined tumours were noted on his scalp. Palpation of the abdomen revealed left-sided tenderness and rigidity. Radiographs of the abdomen showed a few fluid levels, mainly in the ascending colon. Radiographs of the skull showed several irregular translucent areas in the outer table of the cranial vault with overlying soft tissue swelling.

Laparotomy was performed on the day of admission. A tumour was found in the ileum causing obstruction to the lumen, and the wall had perforated proximal to the tumour (Fig. 3). The affected segment of ileum was resected and end-to-end anastomosis performed.

Examination of the specimen removed showed a round tumour, $4 \mathrm{~cm}$. in diameter, yellow brown in colour, and superficially necrotic. Cross section showed a firm, grey-white mass infiltrating the entire gut wall. In the root of the mesentery, the mesenteric glands were infiltrated with tumour.

Histology showed a reticulosarcoma (Fig. 4).

Sections of the small bowel mucosa away from the tumour showed villous atrophy consistent with that found in idiopathic steatorrhoea.

The tumours in the scalp were considered to be secondary deposits and were irradiated. This produced considerable regression in the size of the tumours, and the

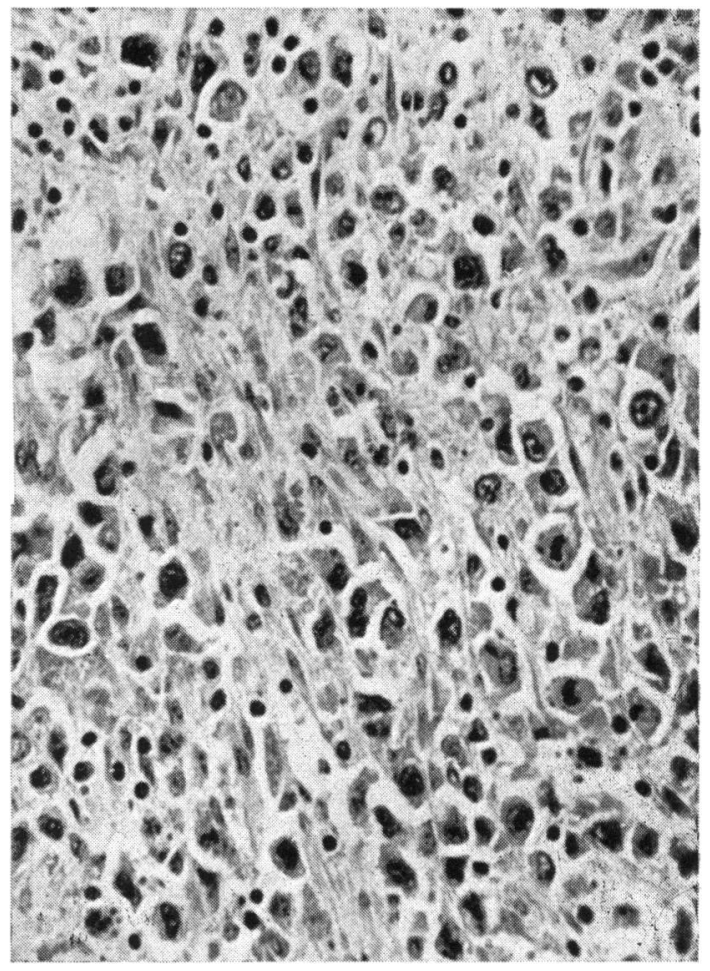

FIG. 4. Case 2. Photomicrograph of ileal tumour $(\times 350)$ showing a reticulum cell reticulosarcoma of pleomorphic character with frequent mitoses.

patient was discharged from hospital on 9 March 1961. When last seen (November 1961) the patient reported three or four loose motions per day, but otherwise had no complaints.

CASE 3. A 48-year-old housewife enjoyed good health until sometime in 1958 when she began to complain of intermittent diarrhoea, with pale, loose, offensive motions, loss of weight, and soreness of the tongue. Early in 1959 her family doctor noted some pallor of the mucous membranes and referred her to hospital as a possible case of pernicious anaemia.

She was admitted to hospital for investigation in April 1959. Pigmentation of the face and arms was noted, which the patient had observed for the past 12 months. There was no buccal pigmentation and the blood pressure was $130 / 80 \mathrm{~mm}$. Hg. Pallor of the mucous membranes and a smooth atrophic tongue were the only other abnormal physical signs. She weighed 6 stone $7 \mathrm{lb}$.

The haemoglobin was $65 \%$, with evidence of both iron deficiency and macrocytosis in the blood film; the E.S.R. was $40 \mathrm{~mm}$. in one hour, W.B.C. 3,600 per c.mm., with a normal white cell distribution.

A faecal fat analysis on a $50 \mathrm{~g}$. daily fat intake revealed a total fat excretion of $37 \mathrm{~g}$. in five days, an average of $7 \cdot 4$ g. per day. 


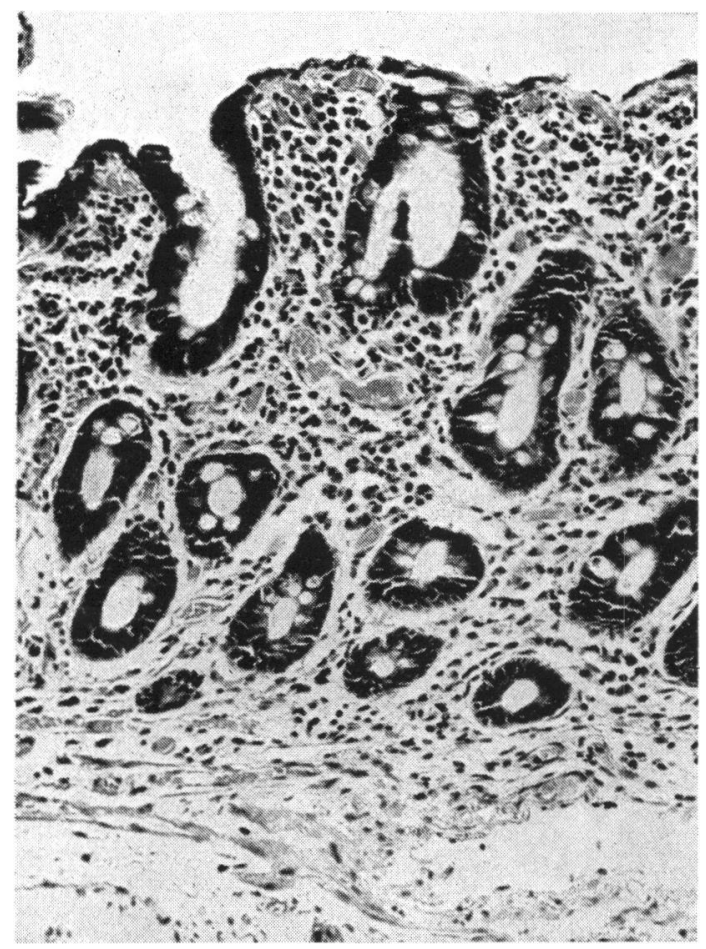

FIG. 5. Case 3. Peroral jejunal biopsy $(\times 175)$ showing subtotal villous atrophy compatible with idiopathic steatorrhoea.

Steatorrhoea was thus shown to be present, but no aetiological diagnosis was made. Treatment with iron and folic acid by mouth and a low-fat diet produced a marked clinical improvement. By December 1959 she had gained 1 stone in weight and the haemoglobin had risen to $90 \%$ with normocytic, normochromic red cells.

This improvement was maintained until August 1960 when the diarrhoea returned with four or five stools per day and she began to lose weight again. She was seen for the first time by us in December 1960 . Her weight was 6 stone $3 \mathrm{lb}$. The pigmentation was noted as before. The mucous membrane were pale, the tongue smooth and atrophic.

Haemoglobin was $56 \%$ M.C.H.C. $32 \%$, P.C.V. $24 \%$, E.S.R. $60 \mathrm{~mm}$. in one hour, W.B.C. 4,200 per c.mm. (polymorphs 3,500 per c.mm.). Examination of the bone marrow showed megaloblastic erythropoiesis. The fiveday fat excretion on a $100 \mathrm{~g}$. daily fat intake was $89 \mathrm{~g}$. (average 18g./day). Radiological small bowel studies showed that the small bowel outlined rapidly and showed irregular segmental dilatation, coarsening of the transverse pattern, and flocculation of barium. Slight dilatation of ileal loops was noted.

Peroral jejunal biopsy (Fig. 5) showed changes consistent with idiopathic steatorrhoea.

After $50 \mathrm{~g}$. of oral glucose the maximum rise in blood sugar was $30 \mathrm{mg} . / 100 \mathrm{ml}$. at 60 minutes.
Tests for occult blood were negative in three specimens.

A diagnosis of idiopathic steatorrhoea was made, and treatment with folic acid, ferrous sulphate, and calcium lactate by mouth, and a monthly intramuscular injection of calciferol was recommended. The patient remained in hospital seven weeks, during which time she was afebrile. Her weight on discharge on 26 February 1961 was 6 st. $12 \mathrm{lb}$., a gain of $9 \mathrm{lb}$. while in hospital. She remained in good health until the end of April 1961 when she again began to lose weight and, for the first time, to complain of colicky upper abdominal pain, occasionally associated with episodes of vomiting. An additional feature was a change in the texture of her hair, which became dry and brittle and fell out in large quantities. She was admitted to hospital on 30 May 1961. Her weight on admission was 6 st. $1 \frac{1}{2} \mathrm{lb}$. The day after admission she began to run a pyrexia of $99^{\circ}$ to $101^{\circ} \mathrm{F}$., and the episodes of severe colicky pain in the right hypochondrium continued.

The physical signs were essentially the same as on her previous admission. Further investigations showed the E.S.R. to be $54 \mathrm{~mm}$. in one hour, the W.B.C. 11,000 per c.mm., and examination of the stools showed the presence of occult blood. $X$-ray studies of the small bowel were unchanged from the previous examination.

The abdominal pain and pyrexia continued, and early in July 1961 a vague abdominal mass could be felt in the umbilical region. Laparotomy was performed on 11 July 1961. A mass was found in the upper jejunum, involving about 2 feet of intestine, and adherent to transverse colon and mesentery. The main mass was excised and end-to-end anastomosis performed.

A segment of jejunum $32 \mathrm{~cm}$. in length had been excised. This contained two deep ulcers with massive necrosis of the whole thickness of the bowel wall. The mucosa of the edge of the ulcer was greatly thickened $(1.5 \mathrm{~cm}$.), but both ulcers had perforated centrally.

Histology showed a reticulosarcoma.

There were no post-operative complications; the pyrexia fell the day after operation and remained normal until discharge on 23 July. The patient died suddenly at home three weeks later. No necropsy could be obtained.

\section{DISCUSSION}

Intestinal reticulosis has been recognized as a cause of steatorrhoea for many years. The present paper, however, suggests that patients with coeliac disease or idiopathic steatorrhoea of long standing may develop small bowel reticulosis as a complication. Cases 1 and 2 recorded here may reasonably be regarded as cases of idiopathic steatorrhoea who developed reticulosarcoma as late complications. In Case 1, the long history of weight loss and diarrhoea, together with the remission of symptoms induced by treatment, would be compatible with such a diagnosis. Case 2 exhibited the classical features of idiopathic steatorrhoea: a 25-year history of loose, pale motions, the clinical features of wasting, atrophic tongue and angular stomatitis, a flat glucose tolerance curve, megaloblastic anaemia, 
typical radiological appearance of the small bowel, the villous atrophy of the jejunum demonstrated by peroral biopsy and finally the excellent response to a gluten-free diet, make such a diagnosis firm. It seems highly unlikely that the reticulosarcoma could have been present in the ileum as long as 25 years, or that it could have caused such a profound disturbance of small bowel function.

Case 3, while showing many of the features of idiopathic steatorrhoea, including the classical changes in the jejunal mucosa, had a much shorter history than the first two cases. In addition, she had a persistently raised E.S.R. throughout, an uncommon finding in patients with uncomplicated idiopathic steatorrhoea. It is, therefore, possible that the reticulosarcoma was present throughout the two years she attended hospital, but if so, an explanation must be found for the histological changes in the jejunal mucosa. It is theoretically possible that the villous atrophy could have been caused by some distant effect of the reticulosarcoma, but if this is the case, then present methods of histological examination are quite unable to differentiate between the mucosal changes in this patient and those seen classically in idiopathic steatorrhoea. The possibility remains that this patient had idiopathic steatorrhoea finally complicated by the reticulosarcoma.

The histological features of the tumour in each of these cases showed striking similarities. Each was a reticulum cell reticulosarcoma of pleomorphic character with numerous mitoses and some multinucleated cells.

Since Fairley and Mackie in 1937 reported steatorrhoea occurring in patients with reticulosis of the small bowel or mesentery several reports have appeared in the literature (Table I). In every case the authors have assumed that the reticulosis caused the steatorrhoea, irrespective of the extent and size of the neoplastic involvement. Opinion appears divided at present as to what structures must be involved to cause steatorrhoea. Comfort (1958) regards involvement of the mesenteric glands, without involvement of the intestinal wall, as a cause of steatorrhoea, whereas Cooke (1958) believes that involvement of the gut wall must take place before steatorrhoea may arise. However, involvement of the mesenteric glands only would seem an unlikely cause for the widespread disturbance of small bowel function indicated by impairment of the absorption of carbohydrate, vitamins, and folic acid. In these cases a diffuse mucosal abnormality, such as exists in idiopathic steatorrhoea, would seem a more probable cause. In the absence of diffuse, malignant infiltration of the small bowel, and in the presence of gross malabsorption, a pre-existing state of idiopathic steatorrhoea may be logically assumed. Furthermore, of the
29 cases recorded by the authors listed in Table $\mathbf{I}$, here are other grounds for suggesting that 16 of them may have suffered from long-standing coeliac disease, idiopathic steatorrhoea, or tropical sprue. The points suggesting this possibility are as follows:

LENGTH OF HISTORY If a patient was reported with a history of diarrhoea for several years, then we considered that a reticulosis would be an unlikely cause. In Case 10, for example, the patient reported by Scudamore (1961), the diarrhoea and abdominal distension had been present since childhood (i.e., for 27 years) and it seems unlikely that the jejunal reticulosis had been present all that time. Similarly, Case 12 had a history very suggestive of coeliac disease in childhood, since at the age of 9 the patient weighed only $35 \mathrm{lb}$. and had suffered from diarrhoea, abdominal distension, and cachexia for several years. All his life he had suffered from bloating and upper abdominal discomfort, and finally died at the age of 71 with a lymphosarcoma of the small bowel. It is suggested (Table I) that these cases were examples of coeliac disease, with the reticulosis as late complications.

A flat Glucose tolerance CURVE $A$ rise in the level of true glucose in the blood of less than $40 \mathrm{mg}$./ $100 \mathrm{ml}$. after the ingestion of $50 \mathrm{~g}$. of glucose has been regarded as suggestive of idiopathic steatorrhoea if there was no involvement of the upper small bowel by the reticulosis.

A MACROCYTIC (OR MEgAlOBLASTIC) ANAEMIA This is also regarded as likely evidence of a widespread disorder of the small bowel, and in the absence of diffuse infiltration by the reticulosis, has been accepted as evidence suggesting idiopathic steatorrhoea.

CLINICAL REMISSION ON A GLUTEN-FREE DIET This is regarded as strong evidence that adult coeliac disease or idiopathic steatorrhoea was the original pathological process but conflicts with the conclusion reached by Best and Cook (1961). They recorded a patient (Case 15, Table I) who was diagnosed in 1955 as a case of idiopathic steatorrhoea. The grounds for such a diagnosis appear excellent, since at that time the patient gave a history of weight loss, diarrhoea with bulky stools, and a sore tongue for at least one year. He was shown to have a megaloblastic anaemia, steatorrhoea, a very flat glucose tolerance curve, and returned to perfect health on a gluten-free diet. Three years later he relapsed, with fever and weight loss and laparotomy revealed mesenteric reticulosarcoma. The authors suggested that the reticulosarcoma was the cause of the com- 
TABLE I

PREVIOUSLY RECORDED CASES

\begin{tabular}{|c|c|c|c|c|c|c|c|c|c|}
\hline \multirow[t]{2}{*}{ Author(s) } & \multirow{2}{*}{$\begin{array}{l}\text { Case } \\
\text { No. }\end{array}$} & \multirow{2}{*}{$\begin{array}{l}\text { Age } \\
(y r .)\end{array}$} & \multirow[t]{2}{*}{ Sex } & \multirow{2}{*}{$\begin{array}{l}\text { Duration of } \\
\text { Symptoms } \\
\text { before } \\
\text { Diagnosis of } \\
\text { Steatorrhoea }\end{array}$} & \multirow{2}{*}{$\begin{array}{l}\text { Site and Type } \\
\text { of Reticulosis }\end{array}$} & \multirow{2}{*}{$\begin{array}{l}\text { Duration of } \\
\text { Life after } \\
\text { Diagnosis of } \\
\text { Steatorrhoea }\end{array}$} & \multicolumn{3}{|c|}{ Features Suggesting Association of Steatorrhoea } \\
\hline & & & & & & & $\begin{array}{l}\text { Coeliac } \\
\text { Disease }\end{array}$ & $\begin{array}{l}\text { Idiopathic } \\
\text { Steatorrhoea }\end{array}$ & Tropical Sprue \\
\hline \multirow[t]{3}{*}{$\begin{array}{l}\text { Fairley and } \\
\text { Mackie (1937) }\end{array}$} & 1 & 42 & $\mathbf{F}$ & $\begin{array}{l}\text { Several } \\
\text { years }\end{array}$ & $\begin{array}{l}\text { Mesenteric } \\
\text { glands. } \\
\text { Peripheral node } \\
\text { biopsy showed } \\
\text { Hodgkin's disease }\end{array}$ & $\begin{array}{l}\text { Patient alive at } \\
\text { time of report }\end{array}$ & & & $\begin{array}{l}\text { Residence in tro- } \\
\text { pics many years. } \\
\text { Several years 'ill } \\
\text { health', with loss } \\
\text { of weight, diarr- } \\
\text { hoea, and } \\
\text { abdominal dis- } \\
\text { tension. Flat } \\
\text { glucose tolerance } \\
\text { curve maximum } \\
\text { rise }=17 \text { mg./100 } \\
\text { ml. }\end{array}$ \\
\hline & 2 & 33 & $\mathbf{F}$ & $13 \mathrm{mth}$. & $\begin{array}{l}\text { Peripheral } \\
\text { lymph node = } \\
\text { lymphosarcoma } \\
\text { (necropsy not } \\
\text { performed) }\end{array}$ & $4 \mathrm{mth}$. & & & $\begin{array}{l}\text { Residence in tro- } \\
\text { pics many years. } \\
\text { Flat glucose } \\
\text { tolerance curve } \\
\text { maximum rise = } \\
10 \mathrm{mg} . / 100 \mathrm{ml} .\end{array}$ \\
\hline & 3 & 60 & $\mathbf{M}$ & $\begin{array}{l}\text { Not } \\
\text { stated }\end{array}$ & $\begin{array}{l}\text { Peripheral node } \\
\text { biopsy = } \\
\text { 'lymphosarcoma' }\end{array}$ & $\begin{array}{l}\text { Still alive at time } \\
\text { of report more } \\
\text { than } 2 \text { yr. after } \\
\text { diagnosis of } \\
\text { steatorrhoea }\end{array}$ & & & $\begin{array}{l}\text { Residence in tro- } \\
\text { pics many years. } \\
\text { Macrocytic } \\
\text { anaemia }\end{array}$ \\
\hline \multirow[t]{2}{*}{$\begin{array}{l}\text { Salvesen and } \\
\text { Kobro (1939) }\end{array}$} & 4 & 60 & $\mathbf{M}$ & $14 \mathrm{yr}$. & $\begin{array}{l}\text { Jejunal ulcers } \\
\text { (1 perforated) } \\
\text { 'isolated lympho- } \\
\text { granulomatosis' }\end{array}$ & 2 mth. & & $\begin{array}{l}\text { Long history of } \\
\text { anaemia, respond- } \\
\text { ing to iron and } \\
\text { liver }\end{array}$ & \\
\hline & 5 & 57 & $\mathbf{M}$ & $10 \mathrm{mth}$. & $\begin{array}{l}\text { Jejunal ulcer } \\
\text { 'isolated lympho- } \\
\text { granulomatosis' }\end{array}$ & $1 \mathrm{mth}$. & & $\begin{array}{l}\text { Initial diagnosis } \\
\text { of pernicious } \\
\text { anaemia, im- } \\
\text { proved with liver. } \\
\text { Flat glucose } \\
\text { tolerance curve }\end{array}$ & \\
\hline $\begin{array}{l}\text { Salvesen } \\
\text { (1948) }\end{array}$ & 6 & 53 & $\mathbf{M}$ & $18 \mathrm{mth}$. & $\begin{array}{l}\text { Perforating } \\
\text { lymphosarcoma } \\
\text { of jejunum and } \\
\text { mesentery }\end{array}$ & 2 mth. & & $\begin{array}{l}\text { Long history } \\
\text { macrocytic } \\
\text { anaemia. Flat } \\
\text { glucose tolerance } \\
\text { curve }\end{array}$ & \\
\hline $\begin{array}{l}\text { Bjerkelund } \\
(1950)\end{array}$ & 7 & 44 & $\mathbf{M}$ & 2 yr. & $\begin{array}{l}\text { 'Lymphogranu- } \\
\text { loma' small } \\
\text { intestine }\end{array}$ & $12 \mathrm{mth}$. & & $\begin{array}{l}\text { Long history } \\
\text { macrocytic } \\
\text { anaemia, flat } \\
\text { glucose tolerance } \\
\text { curve }\end{array}$ & \\
\hline $\begin{array}{l}\text { Harrison et al. } \\
\text { (1977) } \\
\text { continued on pag }\end{array}$ & ge 238 & 44 & $\mathbf{F}$ & 12 mth. & $\begin{array}{l}\text { Lymphosarcoma } \\
\text { of ileum }\end{array}$ & $21 \mathrm{mth}$. & & $\begin{array}{l}\text { Long history, flat } \\
\text { glucose tolerance } \\
\text { curve }\end{array}$ & \\
\hline
\end{tabular}

plete clinical course and that the resulting steatorrhoea was gluten sensitive. We suggest that an alternative explanation is that the patient had idiopathic steatorrhoea, as originally diagnosed, showed the expected response to the gluten-free diet, and that his final deterioration and death were due to the complicating mesenteric lymphosarcoma.

Idiopathic steatorrhoea is now diagnosed with confidence when the characteristic histological appearance of the jejunal mucosa is seen in peroral biopsy specimens. This provides a method of differentiating this condition from other 'secondary' causes of steatorrhoea but at the time the cases in Table I were recorded the method was not available.

However, the assumption that idiopathic steatorrhoea may have been the primary process has been based on the clinical and biochemical data recorded.

Analysis of the relationship between intestinal reticulosis and steatorrhoea from another viewpoint is rewarding, i.e., how often is steatorrhoea a feature of intestinal reticulosis? Skrimshire (1955) reviewed 14 patients who were subjected to laparotomy; all had involvement of the regional lymph nodes. All the patients appeared well nourished and the only 
TABLE I-continued PREVIOUSLY RECORDED CASES



patient suspected of steatorrhoea had a normal fat balance. Rosenberg, Diamond, Jaslowitz, and Craver (1961) reviewed 1,209 patients with lymphosarcomas; 138 had either clinical or necropsy evidence of small bowel involvement. Although some of these patients had diarrhoea none had steatorrhoea and hence it is concluded that intestinal reticulosis is, at best, a rare cause of steatorrhoea.
Examination of the details of the three patients reported in this paper provides some evidence on which to base a clinical suspicion of a reticulosis in a patient with idiopathic steatorrhoea. Failure to respond to a diet, either low in fat or gluten free, in a patient previously shown to have a complete remission, is an important observation. When the relapse is accompanied by a persistent pyrexia and 
a high E.S.R. we believe that reticulosis of the small bowel should be suspected. The occurrence of colicky central abdominal pain is another symptom which should arouse suspicion in a patient with idiopathic steatorrhoea seen in a relapse, and our three patients all had such symptoms. Dermatological manifestations are common in patients with reticulosis, whatever the primary site of origin; two of our patients had evidence of skin involvement. Case 2 developed the erythematous rash and later the secondary deposits in the skin some months before the ileal tumour was clinically apparent. Case 3 complained of generalized pruritus and falling hair during her terminal illness. Radiological examination of the small bowel may fail to provide any evidence of the reticulosis, as in Case 3, and we believe that early laparotomy should be undertaken in any patient with idiopathic steatorrhoea who ceases to respond to treatment and exhibits the clinical features just discussed.

The occurrence of intestinal reticulosis in patients with idiopathic steatorrhoea would seem to be more than a chance association. We have considered the possibility that exposure to diagnostic radiographs may be an aetiological factor. Patients with steatorrhoea often undergo multiple $x$-ray examinations; furthermore barium studies of the small bowel employ relatively large doses of radiation. The total dose of radiation received by our patients during diagnostic procedures was small, but the possibility that irradiation of an abnormal mucosa was of some aetiological importance cannot be entirely excluded.

Another possibility is that the widespread mucosal derangement of the small bowel found in idiopathic steatorrhoea is itself a premalignant condition.

\section{ADDENDUM}

Since this paper was prepared we have had a patient referred to us with a seven-year history of steatorrhoea, responding to a gluten-free diet. In the past two months he had lost weight and had pyrexia and a generalized eczematous eruption. Before routine admission could be arranged he was admitted as an emergency with the signs of obstruction and perforation of the small bowel. At laparotomy malignant ulcers were scattered along the length of the small bowel and the perforated area was resected. Histology has shown the lesion to be a reticulosarcoma.

We have also recently seen the case records of a further possible case of a reticulosarcoma arising in a patient with idiopathic steatorrhoea. A 35-year-old man had suffered from pale, loose motions for 10 years and had attended another hospital where a megaloblastic anaemia was discovered. He failed to respond to vitamin $B_{12}$ injections and some months later he developed intestinal obstruction and died. At necropsy a reticulosarcoma was found obstructing the ileum.

We wish to express our thanks to Professor T. F. Hewer for the pathological reports and for his valuable advice in the preparation of the manuscript.

\section{REFERENCES}

Best, C. N., and Cook, P. B. (1961). Case of mesenteric reticulosarcoma associated with gluten-sensitive steatorrhoea. Brit. med. J., 2, 496-498.

Bjerkelund, C. J. (1950). Symptomatic sprue. Acta med. scand., 137, 130-149.

Comfort, M. W. (1958). Nontropical sprue: diagnosis and therapy. Gastroenterology, 34, 476-483.

Cooke, W. T. (1958). Adult coeliac disease and other disorders associated with steatorrhoea. Brit. med. J., 2, 261-265.

Fairley, N. H., and Mackie, F. P. (1937). The clinical and biochemical syndrome in lymphadenoma and allied diseases involving the mesenteric lymph glands. Ibid., 1, 375-380.

French, J. M., Hawkins, C. F., and Smith, N. (1957). The effect of a wheat-gluten-free diet in adult idiopathic steatorrhoea. Quart. J. Med., n.s. 26, 481-499.

Friedlander, P. H., and Gorvy, V. (1955). Steatorrhoea. Brit. med. J., 2, 809-812.

Harrison, H. E., Harrison, H. C., Tompsett, R. R., and Barr, D. P. (1947). Potassium deficiency in a case of lymphosarcoma with the sprue syndrome. Amer. J. Med., 2, 131-143.

Rosenberg, S. A., Diamond, H. D., Jaslowitz, B., and Craver, L. F (1961). Lymphosarcoma: a review of 1,269 cases. Medicine (Baltimore), 40, 31-84.

Scudamore, H. H. (1961). Observations on secondary malabsorption syndromes of intestinal origin. Ann. intern. Med., 55, 433-447.

Salvesen, H. A. (1948). Symptomatic sprue due to reticulosarcomatosis of the small intestine and the mesentery glands. Gastroenterologia (Basel), 73, 166-172.

__, and Kobro, M. (1939). Symptomatic sprue. Acta med. scand., 102, $277-294$.

Skrimshire, J. F. P. (1955). Lymphoma of the stomach and intestine. Quart. J. Med., n.s. 24, 203-214.

Sleisenger, M. H., Almy, T. P., and Barr, D. P. (1953). The sprue syndrome secondary to lymphoma of the small bowel. Amer. J. Med., 15, 666-674.

Upshaw, C. B., and Pollard, H. M. (1957). The sprue syndrome associated with intra-abdominal lymphoblastoma. Gastroenterology, 33, 104-112. 